\title{
PENEGAKAN HUKUM LINGKUNGAN DALAM BIDANG PENGELOLAAN SAMPAH SEBAGAI PERWUJUDAN PRINSIP GOOD ENVIRONMENTAL GOVERNANCE DI KOTA SURAKARTA
}

\author{
Rosita Candrakirana \\ Fakultas Hukum Universitas Sebelas Maret Surakarta \\ Email : rositakirana@yahoo.com
}

\begin{abstract}
Waste management still be a problems which not yet solved. This research aims to study the problems in waste management in Surakarta. It was a doctrinal/normative legal research using the statute approach, which then analyzed qualitatively. There are laws correlated to waste management in Indonesia, they are Law number 18 Year 2008 on Waste Management, Law No. 32 of 2009 on the Protection and Environmental Management, and some more. The law enforcement in waste management refers to as known as legal system i.e. structure, substance, and culture. There are two kinds of waste management law enforcement; preventive and repressive way. The effectiveness on the enforcement refers to the combination of structure, substance, and law cultures of the community. The effective law enforcement on waste management also indicates the commitment of the government, both local and national, in applying the principles of Good Environmental Government in order to build community awareness on good and healthy environment.
\end{abstract}

Keywords: Effective law enforcement, waste management

\begin{abstract}
Abstrak
Pengelolaan sampah saat ini masih menjadi permasalahan yang belum terselesaikan. Penelitian ini bertujuan untuk mengkaji permasalahan dalam pengelolaan sampah di Surakarta. Penelitian ini adalah penelitian hukum doktrinal/normatif dengan pendekatan perundang-undangan. Data dikumpulkan dengan studi kepustakaan, kemudian dianalisis secara kualitatif. Terdapat beberapa peraturan perundang-undangan yang mempunyai korelasi dengan pengelolaan sampah di Indonesia yaitu Undang-Undang No. 32 Tahun 2009 tentang Perlindungan dan Pengelolaan Lingkungan Hidup dan beberapa undang-undang lainnya. Penegakan hukum dalam pengelolaan sampah mengacu pada 3 sistem hukum yang merupakan gabungan dari komponen-komponen yaitu struktur, substansi, dan budaya. Selain itu berkaitan dengan penegakan hukum dalam pengelolaan sampah dapat dikaji dari 2 sisi yaitu penegakan hukum secara preventif dan represif. Penegakan hukum dalam pengelolaan sampah juga menjadi sebuah perwujudan pemerintah maupun pemerintah daerah dalam menerapkan prinsip Good Environmental Governance dengan tujuan akan menumbuhkan kesadaran bagi masyarakat akan lingkungan hidup yang baik dan sehat.
\end{abstract}

Kata kunci : penegakan hukum, pengelolaan sampah 


\section{A. Pendahuluan}

Pertumbuhan ekonomi masyarakat Indonesia dari tahun ke tahun semakin meningkat diikuti dengan pertumbuhan penduduk. Hal tersebut semakin terasa dampaknya terhadap lingkungan yaitu manusia cenderung merusak lingkungan demi mempertahankan hidupnya. Kualitas lingkungan secara terus menerus semakin menurun sehingga menimbulkan permasalahan degradasi lingkungan pada kehidupan masyarakat. Salah satu permasalahan lingkungan yang masih menjadi problematika di perkotaan yaitu pengelolaan sampah. Menurut Yul H. Harap bahwa sampah merupakan salah satu masalah lingkungan hidup yang sampai saat ini belum dapat ditangani secara baik, terutama pada negara-negara berkembang, sedangkan kemampuan pengelola sampah dalam menangani sampah tidak seimbang dengan produksinya (Waluyo dkk, 2012 : Hal. 3). Menurut Pasal 1 angka (1) UU No. 18 Tahun 2008 tentang Pengelolaan Sampah definisi sampah adalah sisa kegiatan sehari-hari manusia dan/atau proses alam yang berbentuk padat. Sedangkan menurut Pasal 1 angka (5) Pengelolaan sampah adalah kegiatan yang sistematis,menyeluruh, dan berkesinambungan yang meliputi pengurangandan penanganan sampah. Sehingga pengelolaan pada kawasan perkotaan, dewasa ini dihadapkan kepada berbagai permasalahan yang cukup kompleks. Permasalahan-permasalahan tersebut meliputi tingginya laju timbunan sampah, kepedulian masyarakat (human behaviour) yang masih sangat rendah serta masalah pada kegiatan pembuangan akhir sampah (final disposal) (http://mukti-aji.blogspot.com/2008/05/sistem-pengelolaan-sampah-terpadu.html, diakses tanggal 20 November 2014). Selain hal tersebut di dalam masyarakat perkotaan terdapat budaya konsumtif yang mempengaruhi dalam peningkatan kualitas dan jenis sampah. Sehingga dalam pengelolaan sampah tidak akan dapat dipisahkan dengan campur tangan negara dan berbagai sektor yang ada di dalam masyarakat termasuk dunia usaha. Selain itu peran dari masayarakat yang merupakan jejaring atau komunitas pembuang sampah juga mempunyai andil besar dalam pengelolaan sampah dalam hal ini adalah proses daur ulang untuk dapat dimanfaatkan kembali. Sehingga dalam pengelolaan sampah merupakan bagian dari pelayanan publik yang harus diatur dalam regulasi yang diharapkan akan memberikan kenyamanan di dalam kehidupan masyarakat warga seharihari.

Kebijakan berupa pengaturan di Indonesia dirasa belum efektif menimbulkan efek jera kepada masyarakat. Hal tersebut dibuktikan dengan jumlah penduduk 237 juta yang 
diperkirakan akan bertambah menjadi 270 juta penduduk di tahun 2025, diperkirakan jumlah sampah yang akan dihasilkan sebanyak 130.000 ton/hari (http://www.menlh.go.id/hari-peduli-sampah-2014-indonesia-bersih-2020/,diakses tanggal 20 November 2014). Selain itu Indonesia juga didaulat sebagai negara peringkat ke-2 penghasil sampah domestik yaitu sebesar 5,4 juta ton per tahun (http://m.antaranews.com/berita/41728/produksi-sampah-plastikindonesia-54-juta-tonper-tahun, diakses tanggal 20 November 2014). Permasalahan pengelolaan sampah sudah menjadi permasalahan yang krusial karena daerah-daerah (Kabupaten/Kota) juga mengalami banyak kendala dalam pengelolaan sampah. Salah satu hal yang menjadi kendala mengenai penerapan dan penegakan hukum dalam pengelolaan sampah yang merupakan bagian dari penegakan hukum lingkungan terutama dalam penerapan sanksinya. Di Indonesia sebenarnya terdapat beberapa peraturan perundang-undangan yang mempunyai korelasi maupun berkaitan langsung dengan pengelolaan sampah yaitu Undang-Undang No. 32 Tahun 2009 tentang Perlindungan dan Pengelolaan Lingkungan Hidup, Undang-undang Nomor 32 tahun 2004 tentang Pemerintahan Daerah diganti dengan UU No. 23 Tahun 2014 tentang Pemerintahan Daerah, UU No. 18 Tahun 2008 tentang Pengelolaan Sampah dan beberapa peraturan daerah yang sudah dibentuk oleh pemerintah daerah baik di tingkat Kabupaten atau Kota seperti di Peraturan Daerah Kota Surakarta No. 3 tahun 2010 Tentang Pengelolaan Sampah. Sanksi-sanksi yang terdapat dalam peraturan terutama yang menyangkut pengelolaan sampah tidak memberikan efek jera bagi masyarakat yang tidak melakukan pengelolaan sampah dengan berwawasan lingkungan sehingga perlu dikaji mengenai efektifitas sanksi dalam penegakan hukum dalam pengelolaan sampah. Selain itu peran pemerintah daerah juga sangat penting dalam mengeluarkan kebijakan terhadap pengelolaan sampah. Apabila daerah mampu mengelola sampahnya dengan baik maka pelaksanaan terhadap prinsip Good Environmental Governance sudah dapat dikatakan terpenuhi.

\section{B. Metode Penelitian}

Penelitian yang dilakukan adalah penelitian yang bersifat Deskriptif. Jenis penelitian dalam penulisan ini termasuk jenis penelitian hukum doktrinal/normatif. Sedangkan jika dilihat dari sifatnya termasuk penelitian deskriptif dan menurut bentuknya penelitian ini merupakan penelitian diagnostik yakni penelitian yang bertujuan untuk mendapatkan keterangan mengenai sebab-sebab terjadinya suatu gejala atau beberapa gejala. 
Jenis data yang dipergunakan dalam penelitian ini berupa data sekunder, yaitu data atau informasi hasil penelaahan dokumen penelitian serupa yang pernah dilakukan sebelumnya, bahan kepustakaan seperti buku-buku, literatur, koran, majalah, jurnal ataupun arsip-arsip yang sesuai dengan penelitian yang akan dibahas.

Mengacu pendapat Soerjono Soekanto dalam menggunakan data sekunder di bidang hukum ditinjau dari kekuatan mengikatnya dapat dibedakan menjadi 3 (tiga), maka penulis menggunakan data sebagai berikut (Setiono, 2005:19) :

1. Bahan hukum primer, yaitu peraturan perundang-undangan yang berkaitan dengan Pengelolaan Sampah dan hukum lingkungan yaitu Undang-Undang No. 32 Tahun 2009 tentang Perlindungan dan Pengelolaan Lingkungan Hidup, Undang-undang Nomor 23 tahun 2014 tentang Pemerintahan Daerah, UU No. 18 Tahun 2008 tentang Pengelolaan Sampah dan beberapa peraturan daerah yang sudah dibentuk oleh pemerintah daerah baik di tingkat Kabupaten atau Kota seperti di Peraturan Daerah Kota Surakarta No. 3 tahun 2010 Tentang Pengelolaan Sampah.

2. Bahan hukum sekunder merupakan bahan hukum yang memberi penjelasan terhadap bahan hukum primer, terdiri atas : buku-buku, hasil penelitian, hasil penemuan ilmiah, dan artikel yang berkaitan dengan pengaturan pengelolaan sampah.

3. Bahan hukum tersier atau penunjang, yaitu bahan yang memberikan petunjuk maupun penjelasan terhadap bahan hukum primer dan sekunder, dalam makalah ini penulis menggunakan bahan dari media internet, kamus Black’s Law Dictionary, kamus hukum dan Kamus Besar Bahasa Indonesia.

Tehnik pengumpulan data dilakukan dengan studi kepustakaan untuk mengumpulkan dan menyusun data yang berhubungan dengan masalah yang diteliti. Data yang diperoleh dalam penulisan ini bersifat kualitatif, maka analisis dalam penulisan ini adalah analisis data kualitatif dengan pendekatan masalah yaitu Statute Approach (Pendekatan Perundang-undangan) (Peter Mahmud M, 2010 : 96). Dalam hal ini suatu penelitian normatif tentu harus menggunakan pendekatan perundang-undangan, karena yang akan diteliti adalah berbagai aturan hukum yang menjadi fokus sekaligus tema sentral suatu penelitian

\section{Hasil Penelitian dan Pembahasan}

\section{Pengaturan Pengelolaan Sampah di Kota Surakarta}


Problematika mengenai sampah merupakan hal yang sangat penting. Sampah merupakan hal berkaitan dengan budaya dan perilaku masyarakat terutama di wilayah perkotaan. Untuk itu perlu pengelolaan sampah yang benar sesuai dengan peraturan perundang-undangan yang ada. Permasalahan sampah menjadi masalah penting di berbagai wilayah perkotaan (khususnya) yang padat penduduknya. Hal tersebut dikarenakan sebagian besar masyarakat masih memandang bahwa sampah merupakan sisa dari penggunaan suatu barang baik itu organik maupun anorganik yang tidak dapat dimanfaatkan. Sehingga masyarakat dalam mengelola sampah masih bertumpu pada pendekatan akhir (end-of-pipe), yaitu sampah dikumpulkan, diangkut, dan dibuang ke tempat pemrosesan akhir sampah. Padahal, timbunan sampah dengan volume yang besar di lokasi tempat pemrosesan akhir sampah berpotensi melepas gas metan (CH4) yang dapat meningkatkan emisi gas rumah kaca dan memberikan kontribusi terhadap pemanasan global. Agar timbunan sampah dapat terurai melalui proses alam diperlukan jangka waktu yang lama dan diperlukan penanganan dengan biaya yang besar. Dalam pengelolaan sampah pemerintah maupun pemerintah daerah memerlukan kebijakan dalam bidang regulasi yang didasarkan pada peraturanperaturan tingakat nasioal maupun daerah, peraturan tersebut antara lain :

\section{a. Pasal 28 H ayat (1) Undang-Undang Dasar Negara Republik Indonesia Tahun 1945}

Pasal 28H ayat (1) Undang-Undang Dasar Negara Republik Indonesia Tahun 1945 memberikan hak kepada setiap orang untuk mendapatkan lingkungan hidup yang baik dan sehat. Pasal tersebut memberikan konsekuensi bahwa pemerintah wajib memberikan pelayanan publik dalam pengelolaan sampah. Hal itu membawa konsekuensi hukum bahwa pemerintah merupakan pihak yang berwenang dan bertanggung jawab di bidang pengelolaan sampah. Meskipun pengelolaan sampah merupakan kewajiban pemerintah akan tetapi hal tersebut juga dapat melibatkan dunia usaha dan masyarakat yang bergerak dalam bidang persampahan.

Dalam rangka menyelenggarakan pengelolaan sampah secara terpadu dan komprehensif, pemenuhan hak dan kewajiban masyarakat, serta tugas dan wewenang Pemerintah dan pemerintahan daerah untuk melaksanakan pelayanan publik, diperlukan payung hukum dalam bentuk undang-undang. Pengaturan hukum pengelolaan sampah dalam Undang-Undang ini berdasarkan asas tanggung 
jawab, asas berkelanjutan, asas manfaat, asas keadilan, asas kesadaran, asas kebersamaan, asas keselamatan, asas keamanan, dan asas nilai ekonomi (Mulyanto, Jurnal Parental, Volume I Nomor 2 Oktober 2013, 6).

b. Undang-undang Nomor 32 Tahun 2004 tentang Pemerintahan Daerah dicabut oleh Undang-undang Nomor 23 Tahun 2014 tentang Pemerintahan Daerah

Berdasarkan amanah Pasal 18 ayat (2) dan ayat (5) Undang-Undang Dasar Negara Republik Indonesia Tahun 1945 menyatakan bahwa Pemerintahan Daerah berwenang untuk mengatur dan mengurus sendiri Urusan Pemerintahan menurut Asas Otonomi dan Tugas Pembantuan dan diberikan otonomi yang seluas-luasnya. Atas dasar pasal tersebut beserta penjelasannya penyelenggaraan pemerintahan daerah harus didasarkan pada azas desentralisasi, dekonsentrasi, dan tugas pembantuan. Sehingga adanya UU No. 32 Tahun 2004 yang mengatur mengenai kewenangan pemerintah daerah baik Provinsi maupun Kabupaten/Kota terkait pengendalian lingkungan hidup. Meskipun UU tersebut diganti dengan UU No. 23 Tahun 2014 tetap memberikan kewenangan kepada pemerintah daerah. Dalam Pasal 12 UU No. 23 Tahun 2014 bahwa kewenangan kepada pemerintah daerah (pemerintah konkuren) untuk menjalankan urusan pemerintahan wajib yang tidak berkaitan dengan Pelayanan Dasar salah satunya adalah lingkungan hidup.

Dengan adanya pemberian otonomi yang seluas-luasnya kepada Daerah diarahkan untuk mempercepat terwujudnya kesejahteraan masyarakat melalui peningkatan pelayanan, pemberdayaan, dan peran serta masyarakat. Sehingga kewenangan dalam penglolaan sampah merupakan sebuah pelayanan yang diberikan pemerintah daerah dengan memberdayakan masyarakat dan pengelolaan sampah yang berbasis partisipasi masyarakat.

c. Undang-undang No. 32 Tahun 2009 tentang Perlindungan dan Pengelolaan Lingkungan Hidup (UUPPLH)

Pemenuhan lingkungan hidup yang baik dan sehat merupakan hak asasi dan hak konstitusional bagi setiap warga negara Indonesia. Oleh karena itu, pemerintah, pemerintah daerah dan seluruh pemangku kepentingan berkewajiban untuk melakukan perlindungan dan pengelolaan lingkungan hidup dalam pelaksanaan pembangunan berkelanjutan agar lingkungan hidup Indonesia dapat 
tetap menjadi sumber dan penunjang hidup bagi rakyat Indonesia serta makhluk hidup lain. Sehingga pengelolaan sampah yang baik dan benar merupakan wujud dari pemenuhan lingkungan hidup yang baik dan sehat.

Berkaitan dengan pengelolaan sampah bagi pemerintah dan pemerintah daerah tidak dapat lepas dari asas-asas yang terdapat dalam Pasal 2 UU PPLH yang diatur mengenai asas tanggung jawab negara, asas partisipatif, asas tata kelola pemerintahan yang baik; dan asas otonomi daerah. Oleh karena itu pengelolaan sampah merupakan wujud tanggungjawab negara melalui pemerintah dan pemerintah daerah. Dimana dibutuhkan partisipasi masyakat untuk melakukan pengelolaannya. Selain itu diperkuat dengan Pasal 63 UU PPLH yang mengatur mengenai kewenangan pemerintah dan pemerintah daerah dalam perlindungan dan pengelolaan lingkungan hidup. Dimana berdasarkan asas tata kelola pemerintahan yang baik; dan asas otonomi daerah dapat dijadikan acuan dalam pengelolaan sampah.

\section{d. Undang-undang No 18 Tahun 2008 tentang Pengelolaan Sampah}

Dalam UU Pengelolaan sampah didasari dengan Jumlah penduduk Indonesia yang besar dengan tingkat pertumbuhan yang tinggi mengakibatkan bertambahnya volume sampah. Di samping itu, pola konsumsi masyarakat memberikan kontribusi dalam menimbulkan jenis sampah yang semakin beragam, antara lain, sampah kemasan yang berbahaya dan/atau sulit diurai oleh proses alam semakin beragam. Substansi UU ini yang terkait dengan langsung mengenai pengelolan sampah yaitu Pasal 19 mengatur mengenai pengelolaan sampah rumah tangga dan sampah sejenis sampah rumah tangga. Pasal tersebut menyebutkan bahwa pengelolaan sampah rumah tangga dan sampah sejenis sampah rumah tangga terdiri atas pengurangan sampah dan penanganan sampah. Dalam hal pengurangan sampah, lebih lanjut disebutkan dalam Pasal 20 sebagai berikut : Pengurangan sampah yang dimaksud dalam meliputi kegiatan: (1) pembatasan timbulan sampah; (2) pendauran ulang sampah; dan/atau (3) pemanfaatan kembali sampah. Dalam Pasal 20 ayat (2) diatur mengenai pemerintah dan pemerintah daerah wajib melakukan kegiatan sebagai berikut: (1) menetapkan target pengurangan sampah secara bertahap dalam jangka waktu tertentu; (2) memfasilitasi penerapan teknologi yang ramah lingkungan; (3) memfasilitasi penerapan label produk yang 
ramah lingkungan; (4) memfasilitasi kegiatan mengguna ulang dan mendaur ulang; (5) memfasilitasi pemasaran produk-produk daur ulang. Pasal 20 ayat (3) mengatur mengenai pelaku usaha dalam melaksanakan kegiatan yaitu menggunakan bahan produksi yang menimbulkan sampah sesedikit mungkin, dapat diguna ulang, dapat didaur ulang, dan/atau mudah diurai oleh proses alam. Pasal 20 ayat (4) mengatur mengenai masyarakat dalam melakukan kegiatan pengurangan sampah yaitu menggunakan bahan yang dapat diguna ulang, didaur ulang, dan/atau mudah diurai oleh proses alam.

Pasal 22 Undang Nomor 18 Tahun 2008 mengatur mengenai pengelolaan sampah tersebut juga diatur mengenai mengenai penanganan sampah, yang meliputi :

a. pemilahan dalam bentuk pengelompokan dan pemisahan sampah sesuai dengan jenis, jumlah, dan/atau sifat sampah;

b. pengumpulan dalam bentuk pengambilan dan pemindahan sampah dari sumber sampah ke tempat penampungan sementara atau tempat pengolahan sampah terpadu;

c. pengangkutan dalam bentuk membawa sampah dari sumber dan/atau dari tempat penampungan sampah sementara atau dari tempat pengolahan sampah terpadu menuju ke tempat pemrosesan akhir;

d. pengolahan dalam bentuk mengubah karakteristik, komposisi, dan jumlah sampah; dan/atau

e. pemrosesan akhir sampah dalam bentuk pengembalian sampah dan/atau residu hasil pengolahan sebelumnya ke media lingkungan secara aman.

e. Ketentuan yang diatur dalam penyelenggaraan pengelolaan sampah dalam UU No 18 Tahun 2008 tentang Pengelolaan Sampah seharusnya mampu menangani permasalahan mengenai sampah di Indonesia. Sudah menjadi umum bahwa selama ini manajemen sampah masih menerapkan konsep Kumpul-Angkut-Buang (end of pipe). Dengan adanya UU ini , maka manajemen sampah telah mengadopsi konsep 3R: Reduction (Kurangi)-Reuse (gunakan kembali)-Recycling (daur ulang). Demikian halnya dengan paradigma manajemen sampah, bila selama ini menggunakan konsep konvensional yakni sampah dianggap limbah sehingga dibuang yang memerlukan ongkos pembuangan dan pada akhirnya menjadi 
ancaman kesehatan bagi masyarakat. Maka sekarang digunakan paradigma baru yang memandang sampah sebagai sumber daya yang seharusnya diolah kembali sehingga menghasilkan pendapatan yang bermuara pada kesempatan terbukanya lapangan kerja baru dan kesempatan mendapatkan penghasilan baru.

\section{f. Peraturan Daerah Kota Surakarta Nomor 03 Tahun 2010 tentang}

\section{Pengelolaan Sampah}

Dalam penjelasan Perda Kota Surakarta No. 3 Tahun 2010 disampaikan latar belakang pentingnya pengelolaan sampah di daerah khususnya di Kota Surakarta. Faktor yang menjadi pentingnya pengelolaan sampah karena semakin tingginya pertambahan penduduk dan meningkatnya aktivitas kehidupan masyarakat di Kota Surakarta, berakibat semakin banyak timbulan sampah, yang jika tidak dikelola secara baik dan teratur bisa menimbulkan berbagai masalah, bukan saja bagi Pemerintah Daerah tetapi juga bagi seluruh masyarakat. Sampah sebagai sumber daya yang mempunyai nilai ekonomi dan dapat dimanfaatkan. Pengelolaan sampah dilakukan dengan pendekatan yang komprehensif dari hulu, sejak sebelum dihasilkan suatu produk yang berpotensi menjadi sampah, sampai ke hilir, yang kemudian dikembalikan ke media lingkungan secara aman. Pengelolaan sampah dengan paradigma baru tersebut dilakukan dengan kegiatan pengurangan dan penanganan sampah. Pengurangan sampah meliputi kegiatan pembatasan, penggunaan kembali, dan pendauran ulang, sedangkan kegiatan penanganan sampah meliputi pemilahan, pengumpulan, pengangkutan, pengolahan, dan pemrosesan akhir.

Pemerintah merupakan pihak yang berwenang dan bertanggung jawab di bidang pengelolaan sampah meskipun secara operasional pengelolaannya dapat bermitra dengan badan usaha. Selain itu organisasi persampahan, dan kelompok masyarakat yang bergerak di bidang persampahan dapat juga diikut sertakan dalam kegiatan pengelolaan sampah. Pengelolaan sampah di wilayah Kota Surakarta salah satunya adalah usaha untuk mewujudkan Kota Surakarta sebagai kota yang bersih, sehat, rapi dan indah (BERSERI) sesuai dengan visi dan misinya, yang harus dilakukan secara terus menerus dan berkesinambungan.

Pada hakekatnya pengelolaan sampah adalah merupakan kewajiban seluruh komponen masyarakat dan Pemerintah Daerah. Penanganan sampah tidak hanya 
menyangkut masalah teknis dan sistem pengelolaannya saja, akan tetapi juga menyangkut perilaku kehidupan masyarakat, sehingga dengan demikian masalah persampahan tidak akan tuntas tanpa adanya peran serta/partisipasi masyarakat dalam pengelolaannya. Dalam Pasal 3 diatur mengenai tujuan pengelolaan sampah di daerah Surakarta yaitu untuk meningkatkan kesehatan masyarakat, kualitas lingkungan dan menjadikan sampah sebagai sumber daya yang bermanfaat secara ekonomi bagi daerah. Sedangkan dalam Pasal 24 diatur mengenai Pengelolaan sampah rumah tangga dan sampah sejenis sampah rumah tangga terdiri atas: a. pengurangan sampah; dan b. penanganan sampah. Untuk Pengurangan Sampah Pasal 25 yaitu

1) Pengurangan sampah meliputi kegiatan:
a. pembatasan timbulan sampah;
b. pendauran ulang sampah; dan/atau
c. pemanfaatan kembali sampah.

2) Pemerintah Daerah wajib melakukan kegiatan adalah sebagai berikut :
a. menetapkan target pengurangan sampah secara bertahap dalam jangka waktu tertentu;
b. memfasilitasi penerapan teknologi yang ramah lingkungan;
c. memfasilitasi penerapan label produk yang ramah lingkungan;
d. memfasilitasi kegiatan mengguna ulang dan mendaur ulang; dan
e. memfasilitasi pemasaran produk-produk daur ulang.

3) Pelaku usaha dalam melaksanakan kegiatan menggunakan bahan produksi yang menimbulkan sampah sesedikit mungkin, dapat diguna ulang, dapat didaur ulang, dan/atau mudah diurai oleh proses alam.

4) Masyarakat dalam melakukan kegiatan pengurangan sampah menggunakan bahan yang dapat diguna ulang, didaur ulang, dan/atau mudah diurai oleh proses alam.

Dalam Penanganan Sampah daerah kota Surakarta diatur dalam Pasal 27 meliputi : pemilahan dalam bentuk pengelompokan dan pemisahan sampah sesuai dengan jenis, jumlah, dan/atau sifat sampah; pengumpulan dalam bentuk pengambilan dan pemindahan sampah dari sumber sampah ke tempat penampungan sementara atau tempat pengolahan sampah terpadu; pengangkutan 
dalam bentuk membawa sampah dari sumber dan/atau dari tempat penampungan sampah sementara atau dari tempat pengolahan sampah terpadu menuju ke tempat pemrosesan akhir; pengolahan dalam bentuk mengubah karakteristik, komposisi, dan jumlah sampah; dan/atau pemrosesan akhir sampah dalam bentuk pengembalian sampah dan/atau residu hasil pengolahan sebelumnya ke media lingkungan secara aman.

\section{Penegakan Hukum Lingkungan Bidang Pengelolaan Sampah sebagai Perwujudan Prinsip Good Environmental Governance di Kota Surakarta}

Dalam menumbuhkan kesadaran masyarakat dalam pengelolaan sampah maka dibutuhkan adanya sebuah penegakan hukum. Oleh karena itu hukum adalah sarana yang didalamnya terkandung nilai-nilai dan konsep-konsep tentang keadilan, kebenaran, kemanfaatan sosial dan sebagainya (Ridwan HR, 2011 : 291). Sehingga adanya sebuah penegakan hukum meruapakan kegiatan menyerasikan hubungan nilainilai yang terjabarkan didalam kaidah-kaidah/pandangan nilai yang mantap dan mengejawantahkan dan sikap tindak sebagai rangkaian penjabaran nilai tahap akhir untuk menciptakan (sebagai “social engineering”), memelihara dan mempertahankan (sebagai “social control”) kedamaian pergaulan hidup (Soerjono Soekanto dalam Ridwan HR, 2011 : 292). Selain itu penegakan hukum lingkungan adalah suatu tindakan dan/atau proses paksaan untuk mentaati hukum yang didasarkan kepada ketentuan-ketentuan peraturan perundang-undangan dan/atau persyaratan lingkungan (Erwin dalam Syamsul Arifin, 2009: 209). Sehingga penegakan hukum lingkungan di bidang pengelolaan sampah sebagai upaya menerapkan hukum positif dalam kehidupan masyarakat sehingga adanya UU No. 18 Tahun 2008 tetang Pengelolaan Sampah dan peraturan daerah mengenai pengelolaan sampah yang bertujuan untuk memelihara dan mempertahankan kondisi lingkungan agar masyarakat mendapatkan lingkungan yang baik dan sehat.

Penerapan UU No. 18 Tahun 2008 tetang Pengelolaan Sampah dan peraturan daerah mengenai pengelolaan sampah dirasa belum berjalan secara efektif. Hal tersebut dapat dibuktikan dengan Indonesia didaulat sebagai negara peringkat ke-2 penghasil sampah domestik yaitu sebesar 5,4 juta ton per tahun. Selain itu Berat timbunan sampah di Indonesia secara nasional mencapai 200 ribu ton per hari atau setara dengan 73 juta ton per tahun dan paling dominan sampah rumah tangga 
sebanyak 48 persen, pasar tradisional 24 persen, dan kawasan komersial sebesar 9 persen. Sisanya dari fasilitas publik, sekolah, kantor, jalan, dan sebagainya (http//m.liputan6.com/health/read/831503/sampah-di-indonesia palingbanyak-berasaldari-rumah-tangga, diakses tanggal 20 November 2014). Sehingga secara tidak langsung kontributor sampah terbesar rumah tangga baik yang tinggal di kota maupun desa. Data tersebut menjadi salah satu bukti belum efektifnya penegakan hukum dibidang pengelolaan sampah. Pada dasarnya dalam penegakan hukum memang dipengaruhi oleh beberapa faktor, dimana faktor-faktor ini mempunyai hubungan yang erat dan saling mempengaruhi antara satu dengan lainnya. Menurut Soerjono Soekanto dalam bukunya Ridwan HR, faktor-faktor tersebut adalah (Soerjono Soekanto dalam Ridwan HR, 2011: 293):

1. Faktor hukumnya sendiri;

2. Faktor penegak hukum, yang meliputi aparat ataupun lembaga yang membentuk dan menerapkan hukum;

3. Faktor sarana pendukung penegakan hukum;

4. Faktor masyarakat;

5. Faktor kebudayaan, yakni sebagai hasil karya cipta dan rasa yang didasarkan pada manusia dan pergaulan hidup.

Mengacu pada faktor-faktor diatas peran pemerintah dan pemerintah juga sangat penting dalam penegakan hukum dibidang pengelolaan sampah. Adanya peraturan daerah juga sangat penting seperti di Kota Surakarta dengan adanya Peraturan Daerah No. 3 Tahun 2010 mempunyai tujuan agar masyarakat mempunyai kesadaran dalam pengelolaan sampah. Akan tetapi pelaksanaan perda tersebut masih lemah karena pada tahap sosialisasi masih kurang (http://joglosemar.co/2013/07/minim-sosialisasipenegakan-perda-sampah-masih-lemah.html (diakses 20 November 2014). Oleh karena itu Pemerintah Daerah Kota Surakarta belum dapat menerapkan sanksi berupa ancaman dengan pidana kurungan paling lama 3 (tiga) bulan dan/atau denda Rp 50 juta akan tetapi ada tahapan teguran terlebih dahulu dalam penegakan hukum berupa sanksi administrasi.

Dalam upaya penegakan hukum lingkungan memang dapat dilakukan dengan cara preventif dan represif. Penegakan hukum preventif dilakukan melalui pengawasan dan represif dilakukan dengan melalui penerapan sanksi administrasi 
(Mukhlish dan Mustafa Luthfi, 2010 : 41). Sehingga dalam penegakan hukum bidang pengelolaan sampah tidak harus langsung pemberian sanksi administrasi dan pidana akan tetapi upaya preventif sepertinya lebih efektif dalam penerapannya. Penegakan hukum preventif lebih direkomendasikan karena lebih membangun kesadaran masyarakat akan pentinganya pengelolaan sampah yang baik. Beberapa usaha yang sudah dilakukan adalah adanya bank sampah yang mengubah mindset masyarakat bahwa sampah dapat menghasilkan pendapatan. Sebagai contoh di Kota Surakarta di Kelurahan Mojosongo di RT 05/ RW XVI dipelopori oleh tokoh masyarakat setempat yang memberikan contoh mengenai pengelolaan sampah rumah tangga kepada ibu-ibu rumah tangga yang berada di RT 05/ RW XVI yang mana memisahkan sampah organik maupun sampah non-organik. Kemudian secara Door to Door atau komunal dikumpulkan menjadi satu, untuk sampah Non- Organik, ibu - ibu rumah tangga mengumpulkannya ke RT setempat selama 7 hari lalu kemudian oleh Ketua RT dikumpulkan kedalam tong besar selama 30 hari. Lalu dijual kepembeli yang telah disepakati berupa non-produk tidak ada pengolahan lebih lanjut dan tetap dalam bentuk aslinya. Namun untuk sampah organik warga telah mampu mengolahnya menjadi produk pupuk organik yang kemudian dijual (Waluyo dkk, 2012 : 97). Dengan adanya teladan mengenai kesadaran mengelola sampah sehingga masyarakat dapat memanfaatkan sampah menjadi sumber pendapatan. Hal tersebut akhirnya menjadi contoh di kelurahan-kelurahan lain di Kota Surakarta.

Upaya pemerintah dalam penegakan hukum di bidang pengelolaan sampah memang faktor terbesar adalah budaya dalam masyarakat. Sejalan dengan pengertian hukum sebagai sistem hukum dikemukakan antara lain oleh Lawrence M. Friedman yang mengatakan bahwa a legal system in actual operation is a complex organism in which structure, substance and culture interact. Penjelasan masing-masing unsur yaitu:

1. Komponen struktur yaitu kelembagaan yang diciptakan oleh sistem hukum itu dengan berbagai macam fungsi dalam rangka mendukung bekerjanya sistem tersebut. Komponen ini dimungkinkan untuk melihat bagaimana sistem hukum itu memberikan pelayanan terhadap penggarapan bahan-bahan hukum secara teratur. 
2. Komponen substantif yaitu sebagai output dari sistem hukum, berupa peraturanperaturan, keputusan-keputusan yang digunakan baik oleh pihak yang mengatur maupun yang diatur.

3. Komponen kultural yang terdiri dari nilai-nilai dan sikap-sikap yang mempengaruhi bekerjanya hukum (bisa positif dan bisa negatif), atau oleh Friedman disebut kultur hukum. Kultur hukum inilah yang berfungsi sebagai jembatan yang menghubungkan antara peraturan hukum dengan tingkah laku hukum seluruh warga masyarakat atau sebagai "motor penggerak keadilan". Komponen kultur ini hendaknya dibedakan antara internal legal culture yaitu kultur hukum yang dimiliki struktur hukum dan external legal culture yaitu kultur hukum masyarakat luas (Esmi Warasih, 2005: 30).

Dari komponen-komponen diatas bahwa struktur hukum dalam arti pemerintah dan pemerintah daerah mempunyai andil yang besar dalam upaya penegakan hukum dibidang pengelolaan sampah baik secara preventif maupu represif. Selain itu substansi hukum yang ada yaitu UU No. 18 Tahun 2008 dan Peraturan daerah yang mengatur Kabupaten/Kota sebenarnya sudah baik sehingga diperlukan adanya sosialisasi dari pemerintah daerah kepada masyarakat mengenai aturan tersebut. Untuk itu akan mewujudkan budaya hukum di masyarakat akan pentingnya pengelolaan sampah yang baik untuk menciptakan lingkungan yang baik dan sehat.

Pengelolaan sampah yang baik, pada dasarnya adalah merupakan perwujudan penyelenggara pemerintahan yang baik dalam rangka untuk mewujudkan Good Environmental Governance (GEG). Penyelenggaraan pemerintahan berdasarkan prinsip good environmental governance memberikan makna bahwa prinsip-prinsip penyelenggaraan negara yang baik dalam mengelola lingkungan sesuai prinisp sumber-sumber daya alam dan lingkungan (NHT Siahaan, 2009 : 143). Pelaksanaan prinsip-prinsip GEG merupakan perwujudan pemerintah dan pemerintah daerah dalam mendukung terciptanya lingkungan hidup baik dan untuk mewujudkan pelaksanaan pembangunan berkelanjutan.

Dasar pelaksanaan prinsip-prinsip GEG ini adalah Pasal 63 UU PPLH yang mana pasal tersebut diatur mengenai kewenangan pemerintah dan pemerintah daerah dalam mengelola lingkungan hidup. Hal tersebut sejalan dengan pendapat Sonny Kerap yang menegaskan bahwa ada hubungan erat antara penyelenggaraan 
pemerintahan yang baik dengan pengelolaan lingkungan hidup yang baik. Penyelenggaraan pemerintahan yang baik akan mempengaruhi dan menentukan pengelolaan lingkungan hidup yang baik, dan pengelolaan lingkungan hidup yang baik mencerminkan tingkat penyelenggaraan pemerintahan yang baik. Tegasnya, tanpa penyelenggaraan pemerintahan yang baik, sulit mengharapkan akan adanya pengelolaan lingkungan hidup yang baik (Nopyandri, 2011, Jurnal Ilmu Hukum, Volume 2 No.1: 35). Peranan pemerintah dan pemerintah daerah dalam menciptakan pengelolaan sampah juga terdapat dalam Pasal 5,6,7,8,9 UU No. 18 Tahun 2008 yang memuat mengenai tugas dan wewenang dalam pemerintahan. Sehingga pelaksanaan prinsip-prinsip GEG juga dapat mendukung dalam pengelolaan sampah oleh pemerintah dan pemerintah daerah. Adapun unsur-unsur penting di dalam kerangka GEG adalah sebagai berikut (NHT Siahaan, 2009: 144) :

1. Kedaulatan

2. Kekuatan

3. Kebijakan

4. Pengendalian

5. Pengembangan

6. Tanggung jawab

Unsur-unsur dalam prinsip GEG dapat menjadi acuan oleh pemerintah dan masyarakat dalam pengelolaan sampah dalam upaya penegakan hukum lingkungan baik secara preventif maupun represif dalam pengelolaan sampah.

Dalam upaya penegakan hukum lingkungan dibidang pengelolaan sampah selain unsur-unsur dalam GEG terdapat juga kriteria prinsip-prinsip good environmental governance, sebagai berikut (Nopyandri, 2011, Jurnal Ilmu Hukum, Volume 2 No.1: 41-46) :

a. Pemberdayaan masyarakat.

Aspek pemberdayaan masyarakat (people's empowerment) melalui berbagai peluang agar masyarakat dapat terlibat dalam proses pengambilan keputusan, tersedianya akses publik terhadap informasi agar publik dapat berpartisipasi secara efektif, dan hak masyarakat (khususnya masyarakat yang selama ini menggantungkan hidupnya pada sumber daya alam dan ekosistemnya) untuk 
mendapatkan prioritas menikmati dan mendapatkan manfaat dari sumber daya alam tersebut.

b. Transparansi.

Berdasarkan pada aspek transparansi ini, maka setiap rencana kebijaksanaan daerah dalam kaitannya dengan pengelolaan sumberdaya alam dan lingkungan harus diumumkan kepada masyarakat. Dengan demikian memberikan ruang dan kesempatan bagi masyarakat untuk memberikan tanggapan terhadap rencana kebijakan tersebut.

c. Desentralisasi yang demokratis.

Tolok ukur untuk menguji apakah desentralisasi yang demokratis, termasuk pemberdayaan masyarakat lokal dan Dewan Perwakilan Rakyat Daerah (DPRD) diakui serta difasilitasi dalam peraturan perundang-undangan yang terkait dengan pengelolaan sumber daya alam dan lingkungan hidup. Prinsip ini pada dasarnya menghendaki adanya pengaturan peran kepada masyarakat dan DPRD dalam perencanaan ataupun pelaksanaan kebijakan daerah yang terkait dengan pengelolaan sumber daya alam dan lingkungan.

d. Pengakuan terhadap keterbatasan daya dukung ekosistem dan keberlanjutan.

Pengakuan ini sangat penting dilakukan terutama dalam peraturan perundangundangan tentang sumber daya alam tertentu yang rentan terhadap pengurasan, kerusakan dan kepunahan (kehutanan, pertambangan, minyak dan gas, kelautan, sumber daya air). Pengakuan ini tidak terbatas pada pengakuan tekstual (misalnya, pernyataan simbolik dalam suatu mukadimah), akan tetapi secara konsisten pengakuan tersebut mengalir ke dalam tubuh peraturan perundangundangan yang memperjelas langkah-langkah untuk mencegah serta mengurangi pengurasan dan perusakan sumber daya alam, serta pencemaran melalui piranti manajemen lingkungan, instrumen ekonomi, instrumen daya paksa (enforcement atau command \& control), moral suasion maupun kontrol publik.

e. Pengakuan hak masyarakat adat dan masyarakat setempat.

Pengakuan secara tentang hal ini dalam suatu produk hukum sangatlah penting karena pada umumnya masyarakat adat dan masyarakat setempat bergantung hidupnya pada sumber daya alam di sekelilingnya, dan masyarakat adat merupakan penjaga daya dukung ekosistem dan lingkungan mereka. Pengakuan 
terhadap hak-hak mereka juga diperlukan untuk mencegah terjadinya hak-hak mereka dari arus pembangunan dan penanaman modal yang berlangsung dengan sangat cepat.

f. Daya penegakan (Enforceability).

Daya penegakan (Enforceability) ditentukan oleh (a) ketersediaan sanksi yang mampu menimbulkan efek jera (deterrent effect); (b) ketersediaan 3 (tiga) jenis sarana sanksi yang terdiri dari sanksi administrasi, pidana, dan perdata; (c) ketersediaan mekanisme pengaduan masyarakat dan penindaklanjutannya terhadap pelanggaran-pelanggaran hak yang dialami masyarakat; (d) ketersediaan mekanisme pengawasan penataan terhadap persyaratan lingkungan; (e) ketersediaan institusi dan aparat khusus yang melakukan pengawasan penaatan, penyelidikan, penyidikan, penuntutan, bahkan pengadilan.

Berkaitan dengan pengelolaan sampah kriteria-kriteria prinsip GEG yang dapat diterapkan yaitu prinsip pemberdayaan masyarakat, Terkait pengelolaan sampah dalam Pasal 28 UU No. 18 Tahun 2008 diatur mengenai peran masyarakat, antara lain : ayat (1) Masyarakat dapat berperan dalam pengelolaan sampah yang diselenggarakan oleh Pemerintah dan/atau pemerintah daerah. Ayat (2) Peran dapat dilakukan melalui: a. pemberian usul, pertimbangan, dan saran kepada Pemerintah dan/atau pemerintah daerah; b. perumusan kebijakan pengelolaan sampah; dan/atau c. pemberian saran dan pendapat dalam penyelesaian sengketa persampahan. Peran masyarakat juga diatur dalam peraturan daerah khususnya di Kota Surakarta yaitu pada Pasal 35 ayat (1) dan (2) Perda Kota Surakarta No. 3 Tahun 2010 yang mengenai ayat (1) Masyarakat dapat berperan dalam pengelolaan sampah yang diselenggarakan oleh Pemerintah daerah. Ayat (2) peran sebagaimana dimaksud pada ayat (1) dapat dilakukan melalui: a pemberian usul, pertimbangan, dan saran kepada Pemerintah Daerah; b. perumusan kebijakan pengelolaan sampah; dan/atau c. pemberian saran dan pendapat dalam penyelesaian sengketa persampahan. Prinsip Desentralisasi yang demokratis dalam hal ini DPRD yang bertugas untuk membuat peraturan perundang-undangan bersama dengan eksekutif sudah mengakomodasi kepentingan masyarkat dengan adanya UU No. 18 Tahun 2008 tentang Pengelolaan Sampah ditingkat nasional sedangkan ditingkat daerah diterbitkan peraturan daerah contohnya Peraturan Daerah Kota Surakarta No. 3 Tahun 2010 tentang Pengelolaan Sampah. Prinsip Daya penegakan 
(Enforceability) berkaitan dengan pengelolaan lingkungan hidup dalam UU No. 18 Tahun 2008 dan peraturan daerah seperti Perda Kota Surakarta No. 3 Tahun 2010 mengatur mengenai penegakan hukum secara administrasi dan pidana.

Dalam UU No. 18 Tahun 2008 mengatur sanksi administrasi yang berupa paksaan pemerintahan; uang paksa; dan/atau pencabutan izin. Sanksi pidana dalam Pasal 39 yaitu (1) Setiap orang yang secara melawan hukum memasukkan dan/atau mengimpor sampah rumah tangga dan/atau sampah sejenis sampah rumah tangga ke dalam wilayah Negara Kesatuan Republik Indonesia diancam dengan pidana penjara paling singkat 3 (tiga) tahun dan paling lama 9 (sembilan) tahun dan denda paling sedikit Rp100.000.000,00 (seratus juta rupiah) dan paling banyak Rp3.000.000.000,00 (tiga miliar rupiah); (2) Setiap orang yang secara melawan hukum memasukkan dan/atau mengimpor sampah spesifik ke wilayah Negara Kesatuan Republik Indonesia diancam dengan pidana penjara paling singkat 4 (empat) tahun dan paling lama 12 (dua belas) tahun dan denda paling sedikit Rp200.000.000,00 (dua ratus juta rupiah) dan paling banyak Rp5.000.000.000,00 (lima miliar rupiah). Dalam Pasal 40 yaitu (1) Pengelola sampah yang secara melawan hukum dan dengan sengaja melakukan kegiatan pengelolaan sampah dengan tidak memperhatikan norma, standar, prosedur, atau kriteria yang dapat mengakibatkan gangguan kesehatan masyarakat, gangguan keamanan, pencemaran lingkungan, dan/atau perusakan lingkungan diancam dengan pidana penjara paling singkat 4 (empat) tahun dan paling lama 10 (sepuluh) tahun dan denda paling sedikit Rp100.000.000,00 (seratus juta rupiah) dan paling banyak Rp5.000.000.000,00 (lima miliar rupiah); (2) Jika tindak pidana sebagaimana dimaksud pada ayat (1) mengakibatkan orang mati atau luka berat, pengelola sampah diancam dengan pidana penjara paling singkat 5 (lima) tahun dan paling lama 15 (lima belas) tahun dan denda paling sedikit Rp100.000.000 (seratus juta rupiah) dan paling banyak Rp5.000.000.000 (lima miliar rupiah).

Penegakan hukum dalam bidang pengelolaan sampah yang terdapat dalam Perda Kota Surakarta No. 3 Tahun 2010 juga mengatur mengenai sanksi administrasi berupa teguran tertulis paling banyak 3 (tiga) kali; uang paksa; atau pencabutan izin. Selain itu juga menerapkan sanksi pidana dengan pidana kurungan paling lama 3 (tiga) bulan dan/atau denda setinggi-tingginya Rp 50.000.000,00 (lima puluh juta rupiah). Upaya yang berkaitan dengan pemberian sanksi admnistrasi atau sanksi pidana merupakan 
penegakam hukum represif sedangkan pengawasan yang diatur dalam hukum lingkungan administrasi mempunyai fungsi preventif dan fungsi korektif (Takdir Rahmadi, 2011 : 208). Wujud dari fungsi preventif dalam bentuk pengawasan bertujuan agar tidak terjadi pelanggaran pada norma, standar, prosedur, dan kriteria terkait pengelolaan sampah.

\section{Simpulan}

1. Pengaturan mengenai pengelolaan sampah di Indonesia diatur dalam peraturan tingkat pusat dan daerah. Peraturan ditingkat pusat yang mempunyai korelasi terhadap pengelolaan sampah maupun berkaitan langsung dengan pengelolaan sampah yaitu Undang-Undang No. 32 Tahun 2009 tentang Perlindungan dan Pengelolaan Lingkungan Hidup, Undang-undang Nomor 23 tahun 2014 tentang Pemerintahan Daerah, UU No. 18 Tahun 2008 tentang Pengelolaan Sampah dan beberapa peraturan daerah yang sudah dibentuk oleh pemerintah daerah baik di tingkat Kabupaten/Kota contohnya Peraturan Daerah Kota Surakarta No. 3 Tahun 2010 tentang Pengelolaan Sampah. Dalam peraturan-peraturan tersebut diatur mengenai penyelenggaraan pengelolaan sampah yaitu dengan pengurangan dan penanganan sampah yang melibatkan berbagai elemen baik dari pemerintah dan pemerintah daerah serta masyarakat untuk menciptakan lingkungan hidup yang baik dan sehat.

2. Penegakan hukum lingkungan dibidang pengelolaan sampah mengacu pada 3 sistem hukum yang merupakan gabungan dari komponen-komponen yaitu struktur, substansi dan culture/budaya. Selain itu berkaitan dengan penegakan hukum dalam pengelolaan sampah dapat dikaji dari 2 sisi yaitu penegakan hukum secara preventif dan represif. Penegakan hukum dalam pengelolaan sampah juga menjadi sebuah perwujudan pemerintah maupun pemerintah daerah dalam menerapkan prinsip Good Environmental Governance dengan tujuan akan menumbuhkan kesadaran bagi masyarakat akan pentingya pengelolaan sampah.

\section{E. Saran}

Di Indonesia sudah mempunyai berbagai pengaturan mengenai pengelolaan sampah sehingga efektifitas penegakan hukum lingkungannya dapat dilakukan secara preventif dengan melibatkan masyarakat dengan program-program yang berkaitan dengan pengelolaan sampah sehingga mampu menumbuhkan kesadaran masyarakat akan pentingnya lingkungan hidup yang baik dan sehat. Program yang dapat dilakukan oleh 
Pemerintah dan Pemerintah Daerah dengan pengelolaan berbasis masyarakat,misalnya dengan adanya jejaring sampah dan bank sampah sehingga mind set masyarakat bahwa sampah mampu memberikan manfaat dan pendapatan.

\section{F. Persantunan}

Tulisan ini hasil modifikasi dari makalah yang telah dipresentasikan dalam Konferensi Nasional Hukum Lingkungan Tentang “Deforestasi dan Kerusakan Hutan dalam Perspektif Hukum”, Diselenggarakan oleh Universitas Indonesia, Depok, 4-5 Desember 2014

\section{DAFTAR PUSTAKA}

Esmi Warasih. 2005. Pranata Hukum, Sebuah Telaah Sosiologis. Semarang : PT Suryandaru Utama.

Mukhlis dan Mustafa Luthfi. 2010. Hukum Administrasi Lingkungan Kontemporer (Diskursus Pengawasan Pengelolaan Lingkungan Hidup dan Pengembangan Hukum Administrasi di Indonesia). Malang : Setara Press.

Mulyanto. Oktober 2013. "Sistem Pengelolaan Sampah Terpadu (Sipengestu) Kelurahan Serengan dalam Kajian Sosiologi Hukum”. Jurnal Parental. Volume I Nomor 2 Tahun 2013.

NHT Siahaan. 2009. Hukum Lingkungan, Pancuran Alam. Jakarta.

Nopyandri. 2011. "Penerapan Prinsip Good Environmental Governance dalam Perda Kabupaten Sleman Provinsi Daerah Istimewa Yogyakarta. Jurnal Ilmu Hukum, Volume 2 No.1 Tahun 2011.

Peter Mahmud Marzuki. 2010. Penelitian Hukum Normatif. Jakarta : Kencana Prenada Media Group.

Ridwan HR. 2011. Hukum Administrasi Negara Edisi Revisi. Jakarta : PT. Grafindo Persada.

Syamsul Arifin. 2012. Hukum Perlindungan dan Pengelolaan Lingkungan Hidup Di Indonesia. Jakarta : PT Sofmedia.

Setiono. 2005. Metode Penelitian Hukum. Surakarta : Program Pascasarjana UNS.

Takdir Rahmadi. 2011. Hukum Lingkungan di Indonesia. Jakarta : PT. Rajagrafindo Persada.

Waluyo, Ayub Torry Satriyo Kusumo, Rosita Candrakirana. 2012. Laporan Penelitian Hibah Bersaing dengan judul Model Pengelolaan Sampah Kota Berbasis Gender Sebagai Upaya Pengentasan Kemiskinan. Surakarta. Fakultas Hukum Universitas Sebelas Maret.

Undang-undang Nomor 18 Tahun 208 tentang Pengelolaan Sampah.

Undang-undang Nomor 32 tahun 2009 tentang Perlindungan dan Pengelolaan Lingkungan Hidup.

Undang-undang Nomor 23 tahun 2014 tentang Pemerintahan Daerah

Peraturan Daerah Kota Surakarta No. 3 Tahun 2010 Tentang Pengelolaan Sampah.

Internet http://mukti-aji.blogspot.com/2008/05/sistem-pengelolaan-sampah-terpadu.html (diakses tanggal 20 November 2014) 
http://www.menlh.go.id/hari-peduli-sampah-2014-indonesia-bersih-2020/

(diakses tanggal 20 November 2014)

http://joglosemar.co/2013/07/minim-sosialisasi-penegakan-perda-sampah-masihlemah.html (diakses 20 November 2014)

http//m.liputan6.com/health/read/831503/sampah-di-indonesia-paling-banyak-berasaldari-rumah-tangga (diakses tanggal 20 November 2014)

http://m.antaranews.com/berita/41728/produksi-sampah-plastik-indonesia-54-juta-ton-pertahun (diakses tanggal 20 November 2014) 